2019 TheoLogica

An International Journal for Philosophy of Religion and Philosophical Theology

S. I. GOD'S NATURE AND ATTRIBUTES

DOI: https://doi.org/10.14428/thl.v3i2.10263

\title{
Anselm, the Holy Trinity, and the Relative Identity Thesis
}

\author{
CHRISTOPHER HUGHES CONN \\ The University of the South \\ cconn@sewanee.edu
}

\begin{abstract}
Anselm's On the Incarnation of the Word is presented as a letter to Pope Urban II for the purpose of exposing and correcting the theological errors of Roscelin of Compiègne, who maintained that since only the Son became incarnate, we must conclude that the Father, the Son and the Holy Spirit are numerically distinct substances. In this paper I argue that Anselm's rejection of this conclusion involves an account of the Holy Trinity which includes a strongly relativized conception of identity, that is, one which allows an object $x$ and an object $y$ to be the same F, but different Gs. I further contend that Anselm buttresses this account with two nontheological examples of relative identity. Although it may well be the case that advocates of Latin Trinitarianism are generally committed to such an account, since they affirm that the Father is the same substance as the Son but not the same person as the Son, I take Anselm's defense of this position to be theologically significant, first, because it may well be the first explicit defense of Relative Trinitarianism, and second, because Anselm's position as a bishop and a Doctor of the Church is (for Catholics, at least) an indication of its theological soundness.
\end{abstract}

Keywords: Anselm, Relative Identity, Trinity, Incarnation

\section{Introduction}

Anselm's On the Incarnation of the Word is presented as a letter to Pope Urban II for the purpose of exposing and correcting the theological errors of Roscelin of Compiègne. In the course of reconciling his account of the Incarnation with his account of the Holy Trinity, Roscelin contends that if the Father and the Holy Spirit did not became incarnate along with the Son, then the Father, Son and Holy Spirit 


\section{CHRISTOPHER HUGHES CONN}

are numerically distinct substances, "like three angels or three souls". ${ }^{1}$ Since he thinks only the Son became incarnate, Roscelin further concludes that the Father, the Son and the Holy Spirit are indeed numerically distinct substances. In Part Two of this paper I present the argument for these conclusions which Anselm attributes to Roscelin. As we shall see, this argument is surprisingly compelling: the above conclusions are validly derived from premises which appear to be either necessarily true or theologically unexceptionable. In Part Three I examine Anselm's response to this argument. I contend that the debate between Anselm and Roscelin centers around the negated identity-statement "the Father is not the Son". Roscelin takes this statement to be true, on the grounds that only the Son became incarnate, and hence that something is true of the Son which is not true of the Father. Anselm, on the other hand, must say that in its present form this statement is neither true nor false, but incomplete and unintelligible. That is, he must say, with Peter Geach, that this statement is "a vague expression of a halfformed thought" $(1972,238)$. Indeed I hope to show that this anticipation of Geach is far from accidental, since Anselm's response to Roscelin involves an explicit rejection of the classical, absolute conception of identity in favor of a strongly relativized conception of identity according to which it is possible for an object $a$ and an object $b$ to be the same $F$ but different Gs. As we shall see, once Roscelin's argument is modified accordingly, it is either invalid or unsound. It is worth pointing out that Anselm does not take this relativized conception of identity to be restricted to the Holy Trinity, and in Part Four of this paper I outline his favorite non-theological examples of this relation. Finally, in Part Five I briefly explain why I take these results to be significant.

\section{Roscelin's Argument}

In his letter to Pope Urban II Anselm depicts Roscelin as a well intentioned but thoroughly confused defender of the faith. Anselm's reaction is not hard to fathom: in the course of defending the theological integrity of the Christian faith, Roscelin affirms conclusions which are antithetical to this tradition. Even so, it must be said that by Anselm's reckoning Roscelin's basic commitments with regard to these mysteries appear to be theologically sound. In the following passage, for example,

\footnotetext{
${ }^{1}$ Anselm, On the Incarnation of the Word (hereafter, OIW), translated by Richard Regan (Davies and Evans 1990, 238). References and passages from Anselm's Monologion (translated by Simon Harrison), Proslogion (translated by M. J. Charlesworth), and On the Procession of the Holy Spirit (translated by Richard Regan and hereafter, OPHS) are all taken from this volume, with passages being cited in the following manner: OIW 2: 238.
} 
Anselm provides an account of Roscelin's fundamental theological commitments on the grounds that he is a professing Christian:

Therefore, he believes that there is one God, and that God himself is three persons (i.e. Father and Son and Holy Spirit), and that only the person of the Son became flesh (although with the co-operation of the other two persons). ${ }^{2}$

In this passage Anselm characterizes Roscelin as affirming what appears to be a thoroughly orthodox conception of Trinitarian monotheism, namely, one which supposes (i) that there is only one God; (ii) that the one God is the Holy Trinity; (iii) that the Holy Trinity involves three distinct Persons (the Father, the Son and the Holy Spirit); and finally (iv) that only the Son became incarnate. My account of Roscelin's argument for the above conclusions officially begins with the latter pair of claims. Taken together, they state that of the three Persons of the Holy Trinity, only the Son became incarnate. His argument thus begins with premise (1) that the Son became incarnate, and (2) that the Father and the Holy Spirit did not become incarnate along with the Son.

Although Anselm would happily affirm both of these propositions, it soon becomes apparent that he and Roscelin are committed to radically different conceptions of the Holy Trinity. While they would both accept the Boethian thesis that a person is an individual substance of a rational nature, ${ }^{3}$ and hence that each of the three Trinitarian persons is a complete, substantial reality, they would certainly not agree as to how these persons are related to the one God. Whereas Anselm maintains that these persons are the same substantial reality, Roscelin contends that they are numerically distinct substances, "like three angels or three souls". In defense of this position, Anselm takes Roscelin to be reasoning as follows:

If God is numerically one and the same thing, and if the very same thing is Father and Son, how did the Father not also become flesh, since the Son did? Indeed, there is not at the same time a true affirmation of one and the same thing and a denial of it, but nothing prevents affirming about one thing and denying the very same thing about another thing. For example, the same Peter is not (a) an apostle and (b) not an apostle. And if we both by one name affirm the very same person to be an apostle and by another name deny that the person is an apostle, as, for example, affirming that Peter is an apostle, and denying that Simon is, both are not true

\footnotetext{
2 OIW 3: 241.

${ }^{3}$ At Monologion 79: 79 Anselm states that "a person is an independently existing thing".
} 


\section{CHRISTOPHER HUGHES CONN}

statements; rather, one of them is false. But it can be true that Peter is an apostle, and that Stephen is not, since Peter is one person; and Stephen another. Therefore, if the Father is numerically the same thing as, and not a distinct thing from, the Son, it is not true that something should be affirmed of the Son and denied of the Father, or affirmed of the Father and denied of the Son. ${ }^{4}$

In this passage Anselm presents Roscelin as relying upon the principle of indiscernibility which has since been credited to Leibniz, viz., the principle that for any object $x$ and any object $y$, if $x$ is identical with $y$, then every property had by $x$ is also had by $y$ (and vice versa). If Simon is identical with Peter - if "Simon" and "Peter" are co-referring proper names - then it is not possible for something is true of Simon which is not also true of Peter. Since he believes that only the Son became incarnate, and hence that something is true of the Son which is not truth of the Father, Roscelin concludes that the Son is not identical with the Father. Moreover, if the Father and the Son are numerically distinct persons, and every person is an individual substance of a rational nature, then they must also be numerically distinct substances.

The argument which Anselm attributes to Roscelin is both intuitively clear and deductively valid. For the sake of simplicity, let us follow Anselm in restricting our attention to the relationship between the Father and the Son, since our determinations about their relationship can be easily extended to their relationship with the Holy Spirit. This argument begins with the following pair of theologically benign premises:

(1) The Son became incarnate; and

(2) The Father and did not become incarnate along with the Son.

In virtue of his reliance upon the principle of indiscernibility, Roscelin is in position to add three additional premises:

(3) If the Father and the Son are numerically identical, then whatever is true of the Son must also be true of the Father;

(4) If the Father and the Son are not numerically identical, then they are numerically distinct substances; and

\footnotetext{
${ }^{4}$ OIW 3: 241f.
} 
(5) If the Son became incarnate, and everything which is true of the Son is also true of the Father, then the Father became incarnate along with the Son.

At least at first glance, it is difficult to see how one might take issue with any of these additional premises. Indeed, once it is granted that the relation of numerical identity is an absolute equivalence relation which conforms to the principle of indiscernibility, premises (3), (4), and (5) appear to be necessarily true. And since the principle of indiscernibility is generally supposed to be a logical truth, these additional premises could hardly be more secure.

From these five premises Roscelin is in a position to validly infer that the three Trinitarian Persons are numerically distinct substances. Here is an informal reconstruction of the argument, both in standard and diagrammatic form:

\begin{tabular}{l} 
Standard Form \\
\hline (1) The Son became incarnate. \\
(2) It is not the case that the Father become incarnate along with the \\
Son. \\
(3) If the Son is numerically identical with the Father, then whatever \\
is true of the Son is also true of the Father. \\
(4) If it is not the case that the Son is numerically identical with the \\
Father, then the Father and the Son are numerically distinct \\
substances. \\
(5) If the Son became incarnate, and whatever is true of the Son is \\
also true of the Father, then the Father became incarnate along with \\
the Son. \\
$\therefore(6)$ It is not the case that both (i) the Son became incarnate, and (ii) \\
whatever is true of the Son is also true of the Father. (2, 5 MT) \\
$\therefore(7)$ Either (i) The Son did not become incarnate, or (ii) it is not the \\
case that whatever is true of the Son is also true of the Father. (6 \\
DeM) \\
$\therefore(8)$ It is not the case that whatever is true of the Son is also true of \\
the Father. (1,7 DN, DS) \\
$\therefore(9)$ It is not the case that the Son is numerically identical with the \\
Father. (3,8 MT) \\
$\therefore(10)$ The Father and the Son are numerically distinct substances. \\
$(4,9$ MP)
\end{tabular}

Roscelin's argument for the thesis that the Father and the Son are numerically distinct substances involves five deductively valid inferences: the inference from (2) and (5) to (6) is an instance of Modus Tollens; the inference from (6) to (7) is an instance of DeMorgan's Law; the inference from (1) and (7) to (8) involves 


\section{CHRISTOPHER HUGHES CONN}

instances of Double Negation and Disjunctive Syllogism; the inference from (3) and (8) to (9) is an instance of Modus Tollens; and the inference from (4) and (9) to (10) is an instance of Modus Ponens. In the course of presenting Anselm's response to Roscelin's argument, I would like to begin by highlighting the aspects of this argument which Anselm clearly does (or would) accept, and then move on those aspects which he does (or would) reject.

\section{Anselm's Response to Roscelin}

I think it is pretty clear that Anselm would affirm the first three inferences of this argument, both with regard to the truth of their constituent premises, and also with regard to the validity of the constituent sub-arguments. In the first place, he is obviously committed to what is affirmed at (2), the thesis that it is not the case that the Father became incarnate along with the Son. And he is likewise committed to what is affirmed at (5), the thesis that if the Son became incarnate and whatever is true of the Son is also true of the Father, then the Father became incarnate along with the Son. For one thing, this proposition is clearly self-evident. For any $x$ and any $y$, and for any property $F$, if $x$ is $F$ and $y$ has every property that $x$ does, then $y$ must also be F. For another, he shares Roscelin's denial of the thesis that everything which is true of the Son is also true of the Father, since something is true of the Son which is not true of the Father.

Since Anselm accepts what is affirmed at (2) and (5), and these propositions jointly imply what is affirmed at line (6), which further implies what is affirmed at (7), Anselm is obviously committed to what is affirmed at (7), namely, that either it is not the case that the Son became incarnate, or it is not the case that whatever is true of the Son is also true of the Father. Moreover, since he accepts what is affirmed at (1), that the Son become incarnate, he is clearly committed to what is affirmed at line (8), the thesis that it is not the case the everything that is true of the Son is also true of the Father.

Anselm's response to Roscelin's argument must therefore be centered around the final two inferences mentioned above, namely, the inference from (3) and (8) to (9), and the inference from (4) and (9) to (10). Since both inferences are formally valid, what we really need to know is this: which of these propositions does he reject, and on what grounds? We can be confident, in the first place, that he would decisively reject the final conclusion at (10), namely, that the Father and the Son are numerically distinct substances. Anselm contends that this thesis gives rise to a theologically insuperable dilemma. If we grant that three persons of the Holy Trinity are numerically distinct substances, then we must say either (a) that each of 
these substances is an instance of the divine nature, or (b) that each of these substances constitutes a (proper) part of the divine nature. If we say, on the one hand, that each of these substances is an instance of the divine nature, then we must concede that the three divine persons "are three gods rather than one God". ${ }^{5}$ Anselm rejects this possibility, first, because it is contrary to Scripture: "For what does the Sacred Scripture say more openly than there is one and only one God?" 6 He also takes this thesis to be logically absurd, since God is the supreme good, and "the supreme good is the good that surpasses other goods, so that it has neither an equal nor anything that surpasses it." 7

If we say, on the other hand, that each of these substances constitutes a part of the divine nature, and hence that God is the metaphysical union of these substances, we are left with consequences which are no less grave. In the first place, if we say that God is the product of this union, then it would follow that "the Father is not God, the Son is not God, the Holy Spirit is not God, since we should predicate God only of the three mentioned together, and not of each of them or of pairs of them." ${ }^{8}$ In other words, if each of these substances is a proper part of the divine reality, then the Father is not God for the same reason that my left hand is not a human being. In the second place, this would imply that "God is a substance composed of parts and not a simple substance. ${ }^{\prime 9}$ For Anselm it is impossible that God should be composed of parts, since this would mean (among other things) that God's existence would depend upon the existence of something other than God (namely, each of his parts). Even if we were to grant that these substances are essentially and eternally bound to one another (and hence that their metaphysical union is indissoluble), we would still be forced to concede that God is not the ultimate reality, since God's existence would be eternally dependent upon the existence of his proper parts. In short, the thesis that the Triune God is the mereological sum of the three substances has the absurd implication that there exists at least three substances which are (metaphysically speaking) more fundamental than God. Although there are contemporary accounts of the Holy Trinity which endeavor to avoid these implications, ${ }^{10}$ from the standpoints of classical theism and Latin Trinitarianism, these criticisms are formidable indeed.

\footnotetext{
${ }^{5}$ OIW 4: 243.

${ }^{6}$ OIW 2: 238.

7 OIW 8: 248.

8 OIW 4: 244.

${ }^{9}$ Ibid.

${ }^{10}$ See, for example, Wierenga (2004).
} 


\section{CHRISTOPHER HUGHES CONN}

Since Anselm clearly rejects the final conclusion that the Father and the Son are numerically distinct substances, the question at hand is whether he is in a position to avoid this conclusion. Believing as he does that only the Son became incarnate, Anselm is committed to thesis affirmed at (8), namely, that it is not the case that whatever is true of the Son is also true of the Father. Anselm's prospects for avoiding Roscelin's heretical conclusion are thus restricted to the following three propositions:

(3) If the Father and the Son are numerically identical, then whatever is true of the Son must also be true of the Father;

(4) If the Father and the Son are not numerically identical, then they are numerically distinct substances; and

(9) It is not the case that the Son is numerically identical with the Father.

What are his options with regard to these propositions? As a preface to his official response to this triad, I would like to make five initial observations. First, since Anselm both accepts what is affirmed at (8) and denies what is affirmed at (10), he cannot consistently affirm the conditionals in both (3) and (4). If he affirms the conditional at (3), then he is logically committed to what is affirmed at (9), and thus to denying what is affirmed at (4). Conversely, if he affirms the conditional at (4) then he must deny what is affirmed at (9), and this would further commit him to denying what is affirmed at (3).

Second, since the denial of either conditional entails the truth of the other, Anselm cannot consistently deny both these conditionals. Thus, for example, the denial of what is affirmed at (3) would imply that the Son is numerically identical with the Father, and this would further imply the truth of (4) (since in this case it would be a conditional with a false antecedent).

Third, although Anselm cannot consistently affirm or deny both conditionals, he must concede that these statements have at least one thing in common: they both have false consequents: the consequent of (3) falsely maintains that whatever is true of the Son must also be true of the Father, and the consequent of (4) falsely affirms that the Father and the Son are numerically distinct substances.

It thus looks as if Anselm's response to Roscelin's argument hinges upon his response to the thesis that the Son is numerically identical with the Father. Since this thesis is affirmed in the antecedent of (3) and denied in the antecedent of (4), if it is a meaningful proposition which is either true or false, then the truth of what is affirmed at lines (3) and (4) will be determined by the truth or falsity of this proposition: if this identity statement is true, then (3) is false and (4) is true, and if 
it is true then (4) is false and (3) is true. Anselm must now confront the question of whether the Father and the Son are numerically identical.

Finally, it must be said that Anselm appears to have compelling reasons for embracing both of these conditionals. First let us consider his putative reasons for affirming the conditional at (4), namely the thesis that if the Father and the Son are not numerically identical, then they are numerically distinct substances. Anselm repeatedly affirms a sense in which the Father is not identical with the Son: they are distinct persons. And since it was accepted on all hands that a person is an individual substance of a rational nature, Anselm and Roscelin would both concede that every person is a complete substantial being. If the Father and the Son are distinct persons, and every person is an individual substance, then it seems inescapable that the Father and the Son be distinct substances. Indeed if we accept the thesis that identity is an absolute equivalence relation which conforms to the principle of indiscernibility, then this consequence is inevitable, and since this principle is generally taken to be a logical truth it can hardly be considered controversial.

Now consider the case for what is affirmed at (3), the thesis that if the Father is identical with the Son, then everything that is true of the Father is also true of the Son. It should be clear that this conditional does not merely assume the principle of indiscernibility: it is an instance of this principle. That is, it is an instance of the principle that for any object $x$ and any object $y$, if $x$ is identical with $y$, then every property had by $x$ is also had by $y$ (and vice versa). So this statement likewise appears to be thoroughly unexceptionable. Although Anselm cannot consistently affirm both conditionals, he appears to have rather compelling reasons for doing just that.

We now come to the crux of the debate between Anselm and Roscelin. Roscelin's argument relies upon what we now think of as the classical, absolute conception of identity: he takes it to be a dyadic relation which holds, absolutely, between a thing and a thing. That is, for any object $x$ and any object $y$, we can ask whether $x$ and $y$ are one and the same thing, and in every case there is a single, objectively true 'yes' or 'no' answer (this is not to say that we will always know the correct answer, but merely that there must always be a correct answer). In addition, this account presupposes that identity is an equivalence relation which conforms to the principle of indiscernibility. With this conception of identity in place, the conditionals affirmed at (3) and (4) are secure indeed.

I contend that Anselm's response to Roscelin involves an explicit rejection of Roscelin's conception of identity. For he does not think that there is a single, objectively true 'yes' or 'no' answer to the question of whether the Father is 


\section{CHRISTOPHER HUGHES CONN}

identical with the Son. Instead, he maintains that there is one sense in which the Father and the Son are identical (they are the same substance), and there is another sense in which they are not identical (they are distinct persons). Although he defends both claims throughout the whole of OIW 2, his clearest statement to this effect comes in OIW 9. Thus Anselm:

Since the Father and the Son are not two substances, they are not several and distinct from one another as to substance, nor the Father one substance, the Son another; rather, the Father and the Son are one and the same substance. And they are several and distinct from another as to person, since the Father and the Son are two persons and distinct from one another, and not one and the same person. ${ }^{11}$

In this passage Anselm is affirming that the Father and the Son are both distinct persons and the same substance. The paradoxical nature of this claim is hard to avoid: he is affirming (i) that the Father and the Son are distinct persons, (ii) that each of these persons is a divine substance, and (iii) that there is only one divine substance. Indeed Richard Cartwright has argued that this thesis is absurd, on the grounds that "if every A is a B, then there cannot be fewer B's than A's" $(1987,196)$. From this general principle, which he takes to be "evident to the natural light of reason," it follows that if there are three divine persons and each of these persons is a divine substance, there must be at least three divine substances. We will return to this objection shortly.

In what way does Anselm think that the three persons are one substance? Since each of these persons cannot be a part of the divine reality, Anselm contends that each of these persons, by himself, is the whole of this reality. In the opening chapter of OIW, for example, he suggests that we should dismiss the theological reflections of his nominalist counterparts:

Those contemporary (rather, the heretical logicians) who consider universal essences to be merely vocal emanations and who can understand colours only as material substances, and human wisdom only as the soul, should be altogether brushed aside from the discussion of spiritual questions.

For, he continues, one who does not yet understand "how several specifically human beings are one human being" will never be in a position to understand "in the most hidden and highest nature how several persons, each of whom is

11 OIW 9: 248f. 
complete God, are one God."12 Is Anselm really saying both (a) that the Father and the Son are numerically distinct persons, and (b) that each of these persons, by himself, is the whole of the divine reality? Indeed he is. Although this is a most remarkable claim, it is far from isolated. Here are five parallel passages from the Monologion, followed by one from the Proslogion: ${ }^{13}$

The Father, as an individual, is the supreme spirit, and the Son, too, as an individual, is the supreme spirit, and also both of them together are one spirit.

The Father, as an individual, is the supreme spirit. The Son, as an individual, is the supreme spirit. But together Father and Son are one spirit (not two).

The supreme essence, alone, is uncreated and has created all things through itself and nothing but itself. The consequence of this is that the Father, the Son, and also the Love, are each, as individuals, the uncreated Creator without all three, taken together, making several uncreated Creators, but only one.

All three together are one supreme essence (even though each, perfectly, is the supreme essence).

We must, therefore, have faith in Father, in Son, and in their Spirit, equally in each individual and in all three together. This is because each individual is the supreme essence, and all three together are one and the same supreme essence.

And you are so simple that there cannot be born of You anything other than what You are...Nor can there proceed from Your supreme simplicity what is other than that from which it proceeds. Thus, whatever each is singly, that the whole Trinity is altogether, Father, Son, and Holy Spirit; since each singly is not other than the supremely simple unity and the supremely unified simplicity which can neither be multiplied nor differentiated.

In each of these passages Anselm is saying, in the same breath, both (a) that the Father and the Son are numerically distinct persons, and (b) that each of these persons is, by himself, the whole of the divine reality. In other words, he is affirming the self-consciously paradoxical claim that each of the three Trinitarian persons is, by himself, the very God who exists as Father, Son and Holy Spirit.

What Anselm says about the relation between the Father and the Son can only be true on a strongly relativized conception of identity. It should be clear, in the first place, that Anselm is not working with an absolute, dyadic relation, but rather with a relativized, triadic relation. On this account, one cannot coherently ask

\footnotetext{
12 OIW 1: 237.

${ }^{13}$ Monologion 51: 61; 54: 62; 57: 64; 59: 65; 77: 78. Proslogion 23: 100.
} 


\section{CHRISTOPHER HUGHES CONN}

whether an object $a$ is identical with object $b$, simpliciter. Rather, we must ask whether $a$ is the same $F$ as $b$, where ' $F$ ' is the sortal count noun which specifies the respect in which $a$ is (or is not) identical with $b$. In the second place (and this is what makes it a strongly relativized account), Anselm maintains that it is possible for $a$ and $b$ to be the same $F$ but different Gs. For he repeatedly affirms that there is one sense in which the Father and the Son are identical, and another sense in which they are not: they are the same substance but different persons. ${ }^{14}$ In short, Anselm maintains that the Father and the Son are identical in a manner which does not conform to the principle of indiscernibility. In response to his contention that the Father and Son are both (a) "one and the same substance," and (b) "distinct from one another as to person," Anselm anticipates the following objection from Roscelin:

Therefore my adversary says: 'If God the Son became flesh, and he is numerically one and the same thing as the Father, and not distinct from him, then the Father also necessarily became flesh. For it is impossible that a thing numerically one and the same both became flesh and did not become flesh in the same human being. ${ }^{\prime 15}$

Anselm responds to this objection in the following manner:

And I say: 'If the Son became flesh, and he is a different person than the Father is, and not numerically one and the same, then it is not necessary that the Father also became flesh. For it is possible that one person became flesh in a human being, and that another person did not become flesh in the same human being.' ${ }^{16}$

Roscelin's argument explicitly appeals to the principle of indiscernibility, since it is this principle which dictates that if the Father is identical with the Son, then it is impossible that only the Son should have become incarnate. Anselm's rejection of this implication thus commits him to the rejection of this principle. Although he maintains that there is a sense in which the Father and the Son are identical (they

\footnotetext{
${ }^{14}$ It should be noted that this interpretation of Anselm is not without precedent. Cartwright (1987) tentatively suggests that Geach's account of identity is present in OIW, which he characterizes as "a letter written by Anselm of Canterbury to Urban II in 1094" (193). Visser and Williams (2009) provide a much more decisive argument to this effect. Although they concede that "Anselm does not have the technical vocabulary to make the move explicitly," they contend that his replies to Roscelin's heterodox contentions "invite us to give up thinking in terms of absolute or classical identity and to think instead in terms of relative identity" (136).

15 OIW 9: 249.

16 Ibid.
} 
are the same substance), he also contends that it is possible for something to become true of the Son which is not true of the Father (namely, that of becoming incarnate), and he affirms this on the grounds that the Father and the Son are numerically distinct persons. And this commits him to a conception of the Holy Trinity which involves a strongly relativized conception of identity, according to which it is possible for $x$ and $y$ to be the same $F$ but different Gs.

In suggesting that Anselm's account of the Holy Trinity commits him to a strongly relativized conception of identity, I am not merely suggesting that he is logically committed to this analysis of identity, and hence that his account of the Holy Trinity is logically consistent only if it is supplemented with a strongly relativized conception of identity. Although I am convinced that he is committed to relative Trinitarianism in this sense, I think the same could be said for anyone who affirms the basic contours of Latin Trinitarianism. ${ }^{17}$ For how else could one consistently affirm that God exists as three divine persons, such that each of these persons, on his own, is the whole of this reality? How else could one affirm that there is one sense in which the Father and the Son are identical, and another sense in which they are not identical? And how else could one say both that the Son is the same being as the Father, and also that some things are true of the Son which are not true of the Father? What is new here, I submit, is that Anselm is consciously employing a strongly relativized conception of identity in response to Roscelin's objections. Roscelin is quite reasonably insisting upon a doctrine of the Holy Trinity which is informed by an absolute conception of numerical identity which conforms to Leibniz' principle of indiscernibility. Since he believes, with Anselm, that only the Son became incarnate, and hence that something is true of the Son which is not true of the Father, he concludes that the Father and the Son must be distinct substances. Anselm, on the other hand, is clearly allowing his sense of what is possible in this regard to be formed by his understanding of what is actual. Rather than bringing his account of the Holy Trinity in line with the classical account of numerical identity, he is allowing his account of identity to be shaped by his understanding of the Holy Trinity. In particular, he is insisting upon a sense of identity which enables us to say both (i) that the Father is the same being as the Son, and (ii) that the Father is the not the same person as the Son, for then and only then can we consistently affirm that something is true of the Son which is not true of the Father. I thus conclude that in opposition to Roscelin, Anselm is consciously articulating strongly relativized conception of identity which explicitly rejects the

\footnotetext{
${ }^{17}$ For an argument to this effect with regard to Aquinas' account of the Holy Trinity, see Conn (2015, 100-103).
} 


\section{CHRISTOPHER HUGHES CONN}

principle of indiscernibility. Although he does not have the logical or conceptual resources to articulate and defend a formal account of this relation, I do not think it would be fair to say that he is merely gesturing in this direction, or even, with Visser and Williams, that he is "inviting" to think about the Holy Trinity in a manner which is informed by a strongly relativistic conception of identity. ${ }^{18}$ Rather, I contend that in his response to Roscelin he is himself thinking in just this manner. And so I conclude that he is presenting us with an account of the Holy Trinity which explicitly incorporates a strongly relativized conception of identity, the very relation which is since been formally articulated and defended by Geach and van Inwagen.

With these points in mind we are now in a position to consider how Anselm would have responded to Roscelin's argument. As we have seen, since Anselm would have accepted all of the assumptions and inferences which lead to (8), the thesis that it is not the case that everything which is true of the Son is also true of the Father, and since he decisively rejects the final conclusion at (10), which affirms that the Father and the Son are numerically distinct substances, his response to this argument must center around the following propositions:

(3) If the Father and the Son are numerically identical, then whatever is true of the Son must also be true of the Father;

(4) If the Father and the Son are not numerically identical, then they are numerically distinct substances; and

(9) It is not the case that the Son is numerically identical with the Father.

We have already seen both (i) that Anselm can neither affirm nor deny both of the above conditionals, and (ii) that his attitude towards these propositions will be determined by his position with regard to the identity-statement in negated in (9). Anselm must say that in its present form, this statement is neither true nor false. With Geach, he must say that "the Father is not identical with the Son" is "a vague expression of a half-formed thought" (1972, 238). This expression is incomplete because identity is a triadic relation which obtains between an object, an object, and a sortal concept, and only the first two of these three are present here. This statement is thus incomplete in the same way as "Abraham Lincoln has the same as Charles Darwin". Although this statement is neither true nor false in its present (incomplete) form, it is true on some values (e.g., date of birth, gender) and false on others (e.g., parents, occupation, nationality). Moreover, if this is true of

\footnotetext{
18 Visser and Williams $(2009,136)$.
} 
the putative identity-statement contained in (9), then it must also be true of (3) and (4), since they also contain this proposition. Anselm must therefore insist that in its original form, Roscelin's argument fails because its final two inferences involve statements which are neither true nor false.

Since Anselm contends that there is one sense in which the Father and the Son are identical (they are the same substance) and another sense in which they are not identical (they are distinct persons), the path forward is clear: the constituent identity-statements in (3), (4), and (9) must be properly relativized by means of the sortal concepts person and substance. This yields the following three pairs of statements:

(3P) If the Father is the same person as the Son, then whatever is true of the Son must also be true of the Father; and

(3S) If the Father is the same substance as the Son, then whatever is true of the Son must also be true of the Father.

(4P) If the Father and the Son are not the same person, then they are numerically distinct substances; and

(4S) If the Father and the Son are not the same substance, then they are numerically distinct substances.

(9P) It is not the case that the Father is the same person as the Son; and

(9S) It is not the case that the Father is the same substance as the Son.

It is not difficult to see that in each of these pairs there is one statement which Anselm would take to be true and one which he would take to be false. Starting with the third pair, it is clear, first, that Anselm would take what is affirmed at (9P) to be true (it is not the case that the Father is not the same person as the Son), and second, that he would take is affirmed at (9S) to be false (since the Father is the same substance as the Son).

Turning now to the second pair, keep in mind that Anselm takes the consequent of these conditionals to be false: he denies that the Father and the Son are numerically distinct substances. He would thus take what is affirmed at line (4P) to be false, since it has a true antecedent (it is not the case that the Father and the Son are the same person) and a false consequent. On the other hand, he would have to concede that what is affirmed at (4S) is a sort of truism: if the Father and the Son are numerically distinct substances, then they are distinct substances.

Now let us consider the first pair of statements. As before, Anselm takes the consequent of these conditionals to be false: since only the Son became incarnate, it is not the case that everything which is true of the Son is also true of the Father. It 


\section{CHRISTOPHER HUGHES CONN}

is worth noting that Anselm would readily concede that there is a perfectly legitimate sense in which the Father and the Son have exactly the same properties: with regard to the divine essence which each them possesses and indeed which each of them is, there is nothing that is true of the Son which is not also true of the Father. ${ }^{19}$ The difference which Anselm is affirming here between the Father and the Son does not apply to the sense in which they are numerically identical, but rather to the sense in which they are numerically distinct: it is only as distinct persons that something can be true of the Son but not of the Father. Anselm would thus have to say that the conditional affirmed at (3P) is true: if the Father is the same person as the Son, then whatever is true of the Father must also be true of the Son. In other words, if the expressions "the Father" and "the Son" refer to the same person of the Holy Trinity, then everything which is true of the Father must also be true of the Son. The point here is quite similar to Anselm's reasons for affirming (4S). Just as he would grant the truism that the Father and the Son are distinct substances if they are distinct substances, he would also grant that the Father and the Son are same person if they are the same person. And if they are the same person, then everything which is true of the Father (qua person) must also be true of the Son (qua person). Although he might not have said (as we would) that this statement is true because it has a false antecedent and a false consequent, he would of course have been keen to press this observation. This conditional is true because the truth of its antecedent would be a sufficient condition for the truth of its consequent. This situation with regard to (3S) is quite different: although it has the same (false) consequent as (3P), Anselm takes its antecedent to be true: the Father is the same substance as the Son. He must therefore conclude that (3S) is false, while (3P) is true.

We should pause for a moment to reflect on Anselm's denial of the propositions affirmed at (3S) and (4P). To say the least, his denial of these conditionals is quite remarkable. Let us first consider his rejection of the former: although he thinks that there is a sense in which the Father and the Son are identical (they are the same substance), he does not think that this identity-statement commits him to the thesis that everything that is true of the Son is also true of the Father. Indeed he maintains this identity-statement is consistent with the denial of this thesis. That is, he maintains that the Father and the Son are identical in a manner which does not conform to the principle of indiscernibility: although the Father and the Son are one and the same substance, only the Son assumed our nature, so something is true of the Son which is not true of the Father.

\footnotetext{
19 See Monologion 43-44: 55-58.
} 
Now let us consider his denial of what is affirmed at (4P): Anselm contends both (i) that the Father and the Son are numerically distinct persons, and (ii) that the Father and the Son are not numerically distinct substances. Although he accepts the (Boethian) thesis that every person is a substance, he does not think that distinct persons must always be distinct substances. And it should be clear, once more, that he can only (consistently) say this if his account of the Holy Trinity is informed by a strongly relativized conception of identity, i.e., one which allows us to say that the Father and the Son are both (i) distinct persons, and (ii) one and the same substance. In addition, since this instance of relative identity constitutes an exception to Cartwright's general principle that if every A is a B, then there cannot be fewer B's than A's, we can conclude that Cartwright's general principle presupposes an absolute conception of identity, and hence that his appeal to this principle as a basis for rejecting relative Trinitarianism is question-begging.

We are now in a position to consider an extension of Anselm's official response to Roscelin's argument, and we can do this by replacing the incomplete and illformed statements affirmed at lines (3), (4), and (10) with their well-formed counterparts. Let us start with the counterparts which Anselm would take to be true:

(3P) If the Father is the same person as the Son, then whatever is true of the Son must also be true of the Father;

(4S) If the Father and the Son are not the same substance, then they are numerically distinct substances; and

(9P) It is not the case that the Father is the same person as the Son.

With these versions of (3), (4), and (9) in place, the fourth inference is valid, but the final inference is not. As illustrated by Diagram 2 (below), from (3P) and the thesis that it is not the case that everything which is true of the Son is also true of the Father (8), it follows that it is not the case that the Father is the same person as the Son (9P). But from this proposition and (4S), it does not follow that these persons are numerically distinct substances (10), since (9P) is not the antecedent of (4S).

If we replace what is affirmed at lines (3), (4), and (9) with their counterparts which do secure deductively valid inferences, we are left with arguments which depend upon basic premises which Anselm would take to be demonstrably false. We can secure valid inferences either (i) by employing only their person-relative counterparts, or (ii) by employing only their substance-relative counterparts. In the former case (illustrated by Diagram Three), the argument will depend upon (4P), and Anselm has principled reasons for rejecting this proposition: he thinks that the 


\section{CHRISTOPHER HUGHES CONN}

Father and the Son are both (i) distinct persons, and (ii) one and the same substance. In the latter case (illustrated by Diagram Four), the argument will rest upon the conditional affirmed at (3S). Anselm rejects this conditional as a matter of basic orthodoxy, which paradoxically maintains both (i) that the Father and the Son are the same substance, and (ii) that something is true of the Son which is not true of the Father. In short, he maintains that the Father and Son are identical in a manner which does not conform to the principle of indiscernibility.

As we have seen, the argument which Anselm attributes to Roscelin is surprisingly compelling. From premises which appear to be either logically necessary or theologically unexceptionable, Roscelin is able to validly conclude that the Father, the Son and the Holy Spirit are numerically distinct substances, like three angels or three souls. Since Anselm takes this conclusion to be both logically absurd and theologically heretical, it is not surprising that he should respond as forcefully as he does. Even so, the particular nature of his response is more than a little surprising: he avoids Roscelin's conclusion by embracing a strongly relativized conception of identity which does not conform to the principle of indiscernibility. It is important to note, once more, that this is not merely the one avenue which Anselm might have taken: it is the one avenue which he does take. With this analysis in place, Roscelin's theologically unexceptionable premises do not support the thesis that the Trinitarian persons are three substances "like three angels or three souls". In its original form this argument fails because it rests upon propositions which are incomplete and ill-formed, and once its constituent identity-statements are suitably relativized, Roscelin's argument for the above conclusion is either invalid or unsound. 


\begin{tabular}{l}
\hline (3P) If the Father is the same person as \\
the Son, then whatever is true of the \\
Son must also be true of the Father. \\
(3S) If the Father is the same substance \\
as the Son, then whatever is true of the \\
Son must also be true of the Father. \\
(4P) If the Father and the Son are not \\
the same person, then they are \\
numerically distinct substances. \\
(4S) If the Father and the Son are not \\
the same substance, then they are \\
numerically distinct substances. \\
(8) It is not the case that whatever is \\
true of the Son is also true of the \\
Father. \\
(9P) It is not the case that the Father is \\
the same person as the Son. \\
(9S) It is not the case that the Father is \\
the same substance as the Son. \\
(10) The Father and the Son are \\
numerically distinct substances.
\end{tabular}

\section{Two Non-Theological Examples of Relative Identity}

As surprising as it is that Anselm should defend his account of the Holy Trinity by appealing to a strongly relativized conception of identity, it is more surprising still that he should buttress this account with two, non-theological instances of relative identity. One case involves successively made inscriptions which are the same figure (e.g., same point, line or surface), and one involves an analogy involving the Nile River its constituent, geographical parts. ${ }^{20}$ Let us consider these cases in turn.

Anselm does not suppose that instances of relative identity are restricted to the Holy Trinity. In OPHS 16, for example, he writes that "it often happens that several things become one thing under the same name and with the same quantity that

\footnotetext{
${ }^{20}$ For discussions involving the geometrical example, see OIW 15: 258, and OPHS 16: 433. For his discussion of the Nile example, see OIW 13: 255-7, and OPHS 9: 416-418.
} 


\section{CHRISTOPHER HUGHES CONN}

each had before the things became one." In defense of this point he provides the following example:

If we add one point to another without an interval, or if we lay an equal line on an equal line, or if we lay an equal surface on an equal surface, there is constituted only one point, one line, one surface. Anyone, if such a one wished to inquire, will find the like in many things. And so, although there are not several eternities, if we none the less speak of eternity upon eternity, there is in the aforementioned way only one eternity. ${ }^{21}$

In this passage Anselm appears to be suggesting that if we make successive inscriptions in the same manner and location, then we will have produced numerically distinct inscriptions which are the same figure. Suppose, for example, that at $t_{1}$ we make the shortest possible inscription between two points, $x$ and $y$, thus producing line $l$. Suppose, in addition, that we repeat this procedure at $t_{2}$. Anselm maintains that by following this procedure we will have made numerically distinct inscriptions which are the very same line. On the plausible assumption that inscriptions are individuated both by when they are made as well as by where they are made, Anselm is confident that the inscription which was made at $t_{1}$ is numerically distinct from the one which was made at $t_{2}$. Let ' $I 1^{\prime}$ stand for the first of these, and let ' $I_{2}$ ' stand for the second. Anselm does not merely suggest that each of these inscriptions results in a line, he thinks that each of them is a line. It is not hard to understand why he should think this: in response to the question of what $I_{1}$ is, we would surely answer that it is a line, and if this is true of $I_{1}$, it must also be true of I2. Finally, on the assumption that geometrical figures (such as lines) are individuated solely by their spatial coordinates, Anselm is in a position to conclude that $I_{1}$ and $I_{2}$ are the very same line. We thus appear to have a parallel instance of relative identity: there is one sense in which $I_{1}$ and $I_{2}$ are identical (they are the same line), and another sense in which they are distinct (they are distinct inscriptions).

Although I am not convinced that this example works in the way that he thinks it does, ${ }^{22}$ at present I am only concerned with what he takes it to show, namely,

\footnotetext{
21 OPHS 16: 433.

22 These results evidently depend upon the figures in question being abstract objects, and this is not the case with respect to any figure which we might produce. Although we would certainly call $I_{1}$ a line, and though we might well take $I_{1}$ to represent a line in the abstract sense, it is far too thick (inter alia) to be a line in this sense. It is plain, moreover, that this example only works if (i) $l$ is a line in the abstract sense, and (ii) $I_{1}$ and $I_{2}$ are lines in the non-abstract sense. For only then will it be
} 
that even apart from the divine nature it is possible for things to be distinct relative to one description and identical relative to another. It is evident, moreover, that he takes this example to support his account of the Holy Trinity. We see this most clearly in his closing remark, that "although there are not several eternities, if we none the less speak of eternity upon eternity, there is in the aforementioned way only one eternity," which echoes the Athanasian Creed's self-consciously paradoxical affirmation that "the Father is eternal, the Son eternal, the Holy Spirit eternal. Yet there are not three eternals, but one eternal" (Kelly, 1964).

Let us now turn to Anselm's second non-theological example of relative identity. In OIW 13 Anselm concedes that his adversary may be unwilling to suppose that it is possible for three persons to be one and the same substance, "since he does not perceive such in the case of other things, and he cannot understand such in the case of God". ${ }^{23}$ Here is Anselm's initial response to this concern:

Let him allow that there are things in God that his intellect could not understand, and let him not compare the nature that is superior to everything, the nature that is free from every law of time and space and composition of parts, to things that are. Rather, let him profess that there are in that nature what cannot be in the latter things, and let him accept Christian authority and not contest it. ${ }^{24}$

Although he takes his account of the Holy Trinity to be fundamentally grounded in divine revelation, and he clearly understands that it is no part of classical theism or Catholic Christianity that we be in a position to understand everything which has been disclosed about the divine nature, Anselm is not fully content with his initial response. For he remains convinced that we "can in some way find in created things, which are subject to the laws of space and time and composition of parts," what his interlocutor denies in God. ${ }^{25}$ In particular, he is convinced that we can find clear instances of relative identity in the created order, and in support of this claim he offers his analogy between God and the Nile River.

Anselm's Nile analogy begins as follows:

Let us suppose a source from which a river originates and flows, and let us suppose that the river later empties into a delta. Let the river's name be the Nile.

plausible to suppose that $l$ is individuated by its constituent points, while $I_{1}$ and $I_{2}$ are individuated by where they are made and also by when they are made.

23 OIW 13: 255.

${ }^{24}$ Ibid.

${ }^{25}$ Ibid. 


\section{CHRISTOPHER HUGHES CONN}

And so we give the separate names 'source', 'river', 'delta' in such a way that we do not call the source the river or the delta, or the river either the source or the delta, or the delta the source or the river. ${ }^{26}$

Anselm's analogy requires, first, that we take "the Source", "the River" and "the Delta" to function as proper names. In particular, we must suppose (as with "The Father", "The Son" and "The Holy Spirit") that there is a sense in which these expressions are not co-referring names, and hence that the Source is not the River or the Delta, that the River is not the Source or the Delta, and so on. ${ }^{27} \mathrm{He}$ also takes "The Nile" to function as proper name in roughly the same way as "God". That is, he uses "the Nile" or "the whole Nile" to refer to "the running water, the substance, the body of water one." 28 In other words, these expressions denote the effluvial substance in its singular totality.

With these terms in place, Anselm endeavors to extend this analogy with the Holy Trinity in three quite surprising ways. In the first place, although we might take it as obvious that the whole Nile is the union of its Source, River and Delta, he further maintains that this is also true of any two of these realities, and hence that the Source and the River together constitute the whole Nile, and this is likewise true of the Source and the Delta and of the River and the Delta. ${ }^{29}$ More surprising still, he contends that each of these realities, on its own, is the whole Nile. Although the Source is not the River or the Delta, he maintains that "the whole Nile is its source, the whole Nile is its river, the whole Nile is its delta". ${ }^{30}$ Finally, he contends that the Source, the River and the Delta are individuated by their mutual relations. Just as we say that the Father is he who is neither begotten nor proceeding, while the Son is he who is begotten by the Father, and the Holy Spirit is he who proceeds from the Father and the Son, so Anselm insists that "the source

\footnotetext{
${ }^{26}$ Ibid.

${ }^{27}$ If Anselm is advocating a relativized conception of identity, then he cannot consistently suppose that singular terms denote individuals in accordance with the so-called direct theory of reference, since this account is imbued with an absolute conception of identity. As it happens, however, Anselm does not affirm the currently orthodox theory of reference. Rather, he thinks that the referent of a name is determined by the descriptive content which the speaker associates with this name. He thus writes at OIW 11 that "when we speak of this or that human being particularly or Jesus by his proper name, we denote the person, which along with the human nature has a combination of proper characteristics, and these characteristics individualize common human being and distinguish it from other individuals (253). For a more detailed account of Anselm's theory of reference, see Visser and Williams 2009, 31-38.

28 OIW 13: 256.

${ }^{29}$ Ibid., 255.

${ }^{30}$ Ibid., 256.
} 
is not from the river or the delta, and the river is only from the source, not from the delta, and the delta is from the source and the river." ${ }^{31}$

Although it is not hard to understand why Anselm should take the Source, the River and the Delta to jointly constitute the whole Nile, how can he say that any two of these is the whole Nile, much less that any one of them is? Are not the Source, the River and the Delta so many parts of the whole river? Here is Anselm's response to this objection:

If my adversary objects that any single one, whether the source or the river or the delta, or pairs of them, are part or parts of the Nile, from its beginning to its end, let him reflect that the whole Nile, from its beginning to its end, consists of its entire span, as it were, since the entire Nile itself is not immediately entire, either spatially or temporally, but by reason of its parts, nor will it be complete until it ceases to be. (For the Nile is in this respect like speech, which is not complete as long as it flows out of a mouth as its source, as it were, and does not exist when it is complete)..$^{32}$

In his response to the above objection Anselm invokes a distinction between things which persist by enduring through time in their entirety, and things which persist by being temporally extended. He is suggesting, in other words, that the Nile is more like an effluvial event than an effluvial substance, that it is more like a horserace than a horse. Thus, for example, if you were only fortunate enough to have seen the final lap of the last Kentucky Derby, you would not claim to have seen the whole race, but only part of it. It is important to note, however, that you would not say the same about the winning horse. Thus, for example, if you had seen this horse on three different occasions, you wouldn't claim to have seen different temporal parts of this animal at these times. Rather, you would claim to have seen it-the very same individual horse-at three different times. While it is certainly true that the Source and the River and the Delta are individuated by their geographical locations, they do not constitute proper parts of the whole Nile at time any given time $t$, since the whole Nile does not exist at $t$; only a small temporal part of it does. ${ }^{33}$ Thus, for example, if $t$ marks out a one-second interval of this effluvial event, then $t$ would represent a four-dimensional slice of the whole Nile: it would have three (rather expansive) spatial dimensions and one (fairly thin) temporal

\footnotetext{
${ }^{31}$ Ibid.

32 Ibid.

${ }^{33}$ In support of the thesis that Anselm has a concept of temporal parts and their temporally extended sums, see Conn 2011, 260-270.
} 


\section{CHRISTOPHER HUGHES CONN}

dimension. The whole effluvial event, then, would be the sum of its spatial and temporal parts from the first moment of its existence to its last.

Let us suppose that this effluvial event begins at $t_{1}$ and ends at $t_{10}$, and let us consider the entire quantity of water which flowed during this period. If we distinguish between the substance of the water and the event of its flowing, we can see why Anselm should insist that the Source and the River and the Delta (whether individually or in pairs or altogether) are each "the same Nile, the same running water, the same body of water, the same substance". ${ }^{34}$ For the quantity of water which flowed from the Source is the very same quantity of water which flowed both (a) through the River, and (b) into the Delta. Although rivers are fully subject to the laws of space and time, it is at least conceptually possible to suppose that there is one sense in which the Source and the River are both (a) distinct geographical regions and (b) the same body of water. Although his argument to this effect does not strike me as conclusive, I am once again most interested in what Anselm takes it to show, namely, that even in the created order there are instances of relative identity which closely resemble the relations between the three divine persons and the one divine substance.

\section{Conclusion}

In this paper I have argued that in the course of responding to Roscelin's theological errors Anselm provides an account of the Holy Trinity which consciously invokes a strongly relativized conception of identity, i.e., one which allows him to say that the Father and the Son are both the same substance and numerically distinct persons. I have argued, in addition, that he further defends the integrity of this position (with varying degrees of success) by working out two non-theological instances of relative identity. This is significant, in the first place, because Anselm may well have been the first Christian philosopher to establish that the doctrine of the Consubstantial Trinity is logically incompatible with the principle of indiscernibility. What's more, he is almost certainly the first to articulate an account of the Holy Trinity which involves a strongly relativized conception of identity. While Geach is generally acknowledged to be the first to have made this argument in any sort of detail, and while Geach and others have suggested Aquinas' account of the Holy Trinity is logically committed to relative identity, ${ }^{35}$ I submit that the honor of this "theological discovery" (if one can call it

\footnotetext{
34 OIW 13: 256.

35 Thus Geach and Anscombe 1961, 118-120; and Conn 2015, 100-103.
} 
that) belongs to Anselm. I thus take this innovation to be a remarkably fruitful instance of his method of faith seeking understanding: since it is (for Anselm, as for many) an article of faith that the Father and the Son are both (a) distinct persons, (b) one and the same God, he has provided us with account of identity which makes this possible. Finally, since this analysis has only recently been worked out in detail, even those who are impressed by its coherence and fruitfulness may be reluctant to affirm its truth. With Peter van Inwagen-surely the most able defender of this position - we might feel obliged to withhold our assent from this account until its orthodoxy has been established by the appropriate body of theologians $(2003,84)$. Although it is not clear which theologians van Inwagen has in mind here, for any whose confessional allegiances are rooted in the Catholic West, I submit that Anselm's endorsement Relative Trinitarianism is a strong indication of its theological soundness. As a bishop whom the Church has declared to be both a saint and a Doctor of the Church, Anselm is no mere philosopher/theologian: he is a particularly eminent member of the ordinary magisterium. I thus conclude that with Anselm's affirmation of this account, van Inwagen's desire for a proper theological vindication of this analysis has already been partly realized.

\section{Bibliography}

Conn, Christopher. 2011. "Anselmian Spacetime: Omnipresence and the Created Order." The Heythrop Journal 52: 260-270. https://doi.org/10.1111/j.14682265.2009.00560.x.

Conn, Christopher. 2015. "Aquinas, the Incarnation, and the Relative Identity Thesis: A Modest Defense of the Assumptus-homo Theory." The Thomist 79: 75111. https://doi.org/10.1353/tho.2015.0022.

Cartwright, Richard. 1987. "On the Logical Problem of the Trinity." In Philosophical Essays, edited by Richard Cartwright. MIT Press: 187-200.

Davies, Brian; G. R. Evans. 1998. Anselm of Canterbury: The Major Works. Oxford University Press.

Geach, Peter. 1972. Logic Matters. University of California Press.

Geach, Peter and Elizabeth Anscombe. 1961. Three Philosophers. Cornell University Press.

Kelly, J. N. D. 1964. The Athanasian Creed. Harper and Row.

Van Inwagen, Peter. 1995. "And yet they are not Three Gods but One God." In God, Knowledge and Mystery: Essays in Philosophical Theology, edited by Peter van Inwagen. Cornell University Press: 260-279. 
Van Inwagen, Peter. 2003. “Three Persons in One Being: On Attempts to Show that the Doctrine of the Trinity is Self-contradictory. In The Holy Trinity, edited by Melville Stewart. Kluwer Academic Publishers: 83-97. https://doi.org/10.1007/978-94-017-0393-2 9.

Visser, Sandra and Thomas Williams. 2009. Anselm. Oxford University Press. https://doi.org/10.1093/acprof:oso/9780195309386.001.0001.

Wierenga, Edward. 2004. "Trinity and Polytheism." Faith and Philosophy 21 (3): 281294. https://doi.org/10.5840/faithphil200421324.

Published Online: July 08, 2019 